\title{
Production, Purification and Physicochemical Properties of an Exo-Polygalacturonase from Aspergillus niger SW06
}

\author{
Yu-ping Ma, ${ }^{a}$ Hui Hao, ${ }^{a}$ Zhi-fei Chen, ${ }^{a}$ Zhi-wei Zhao, ${ }^{a}$ Shun-hui Chen, ${ }^{b}$ Si-wen Sun ${ }^{c}$ and \\ Chun-ping $X u^{*, c}$ \\ ${ }^{a}$ Technical Center of China Tobacco Henan Industrial Co. Ltd, 450016 Zhengzhou, China \\ ${ }^{b}$ Hennan Cigarette Industry Tobacco Sheet Co. Ltd., 461100 Xuchang, China \\ ${ }^{c}$ College of Food and Biology Engineering, Zhengzhou University of Light Industry, \\ 450002 Zhengzhou, China
}

\begin{abstract}
In this study, exo-polygalacturonase (exo-PG) production from Aspergillus niger SW06 was optimized by central composition design and high amount of 21.51 units $\mathrm{mL}^{-1}$ could be achieved in optimizing growth conditions. Both gel filtration and ion exchange chromatography revealed a single exo-PG activity peak, and sodium dodecyl sulfate polyacrylamide gel electrophoresis (SDS-PAGE) analysis of the purified protein showed a single band with a molecular mass of $66.2 \mathrm{kDa}$. The purified enzyme exhibited maximal activity in the presence of $1 \%$ citrus pectin at the temperature of $55^{\circ} \mathrm{C}$ and $\mathrm{pH}$ of 5.0. The enzyme was stable within the $\mathrm{pH}$ range of 3.0-5.0 and below $60{ }^{\circ} \mathrm{C}$. The Michaelis constant $\left(\mathrm{K}_{\mathrm{m}}\right)$ and maximum velocity $\left(\mathrm{V}_{\max }\right)$ of the enzyme was found to be $0.58 \mathrm{mg} \mathrm{mL}^{-1}$ and $20.66 \mu \mathrm{mol}\left(\mathrm{mL} \mathrm{min}^{-1}\right.$, respectively. The thermostable and acidic nature for the activity of this exo-PG make it possible to have wide range of industrial applications.
\end{abstract}

Keywords: Aspergillus niger, exo-polygalacturonase, purification, characterization

\section{Introduction}

Pectinases are a heterogeneous group of related enzymes which catalyze the degradation of pectic substances, present mostly in the plant cell walls. ${ }^{1}$ Polygalacturonases (PGs) (EC 3.2.1.67) are the pectinolytic enzymes that catalyze the hydrolytic cleavage of the $\alpha-1,4$-glycosidic bonds that link galacturonic acid residues. ${ }^{2,3}$ PGs have been classified according to their substrate specificity and the position of the bonds which they hydrolyze. Endo-PG (E.C. 3.2.1.15) was defined as randomly hydrolyzing the $\alpha-1,4$-glycosidic bonds in the polymer, whereas exo-PG acts sequentially from the nonreducing end. ${ }^{3} \mathrm{PGs}$ are widely distributed in the microbial sources including fungi, bacteria and many types of yeast and also found in higher plants and some plant parasitic nematodes. ${ }^{4}$ PGs are used in several processes, such as paper and pulp industry, fruit juice and wine clarification, tea and coffee fermentation, degumming and retting of plant fibers, and oil extraction, etc. ${ }^{5,6}$

Although several Aspergillus species organisms producing pectinases have been reported and are used in industrial processes in crude form, ${ }^{7,8}$ their selection of potential isolates still remains a tedious task, especially when physiologically potential strains are obtained to achieve maximum yield. ${ }^{9}$ Their purification and knowledge of the biochemical characteristics of these enzymes are important for the understanding of their structure and functional mechanism of action and thermostability. It has been reported that fungal PGs generally are monomeric proteins with a carbohydrate content of $5-85 \%$ and molecular masses in a range from 20 to $95 \mathrm{kDa}$. ${ }^{2,6,10,11}$

In the present study, the production of an exo-PG obtained from Aspergillus niger SW06 by submerged culture was optimized by using a central composite design and response-surface analyses. After the media optimization, exo-PG was purified by both gel filtration and ion exchange chromatography. The physicochemical properties of exo-PG were characterized in terms of optimum $\mathrm{pH}$ and temperatures, and stability at high and low temperatures.

*e-mail: c.p.xu@zzuli.edu.cn 


\section{Experimental}

\section{Microorganism and growth conditions}

The exo-PG producing fungus Aspergillus niger SW06 was isolated from tobacco field in Xuchang, P. R. China, and maintained on the stock medium containing $30 \mathrm{~g} \mathrm{~L}^{-1}$ glucose, $3 \mathrm{~g} \mathrm{~L}^{-1}$ peptone, $5 \mathrm{~g} \mathrm{~L}^{-1} \mathrm{NaCl}, 5 \mathrm{~g} \mathrm{~L}^{-1}$ citrus pectin, $25 \mathrm{~g} \mathrm{~L}^{-1}$ agar (not adjusted) at $4{ }^{\circ} \mathrm{C}$. The liquid culture of mycelia was initiated by transferring the fungal mycelia from the stock culture on a Petri dish into the seed culture medium. The seed culture was propagated in a $250 \mathrm{~mL}$ Erlenmeyer flask containing $100 \mathrm{~mL}$ of liquid medium ( $10 \mathrm{~g} \mathrm{~L}^{-1}$ yeast extract, $5 \mathrm{~g} \mathrm{~L}^{-1}$ citrus pectin, $\mathrm{FeSO}_{4} 0.1 \mathrm{~g} \mathrm{~L}^{-1}$, $\mathrm{MgSO}_{4} 0.5 \mathrm{~g} \mathrm{~L}^{-1}, \mathrm{KH}_{2} \mathrm{PO}_{4} 1 \mathrm{~g} \mathrm{~L}^{-1}$, and $\mathrm{pH}$ 6.0) at $28{ }^{\circ} \mathrm{C}$ on a shaking incubator at $160 \mathrm{rpm}$ for $48 \mathrm{~h}$. Exo-PG was produced with the inoculation of $4 \%(\mathrm{v} / \mathrm{v})$ of the seed culture by submerged fermentation in a stirred tank bioreactor (Infors, Switzerland, 3.5 L working volume). The fermentations were performed under the following conditions: temperature, $28^{\circ} \mathrm{C}$; aeration, 2 vvm; agitation speed, $160 \mathrm{rpm}$. All experiments were performed in triplicate to ensure the trends observed were reproducible.

\section{Confirmation of enzyme type}

After 72 hours of fermentation, the culture broth was centrifuged at $9,000 \times \mathrm{g}$ for $15 \mathrm{~min}$, and the resulting supernatant was filtered through a membrane filter (0.45 $\mu \mathrm{m}$, Millipore). The type of extracelluar PG was determined using following assays.

\section{Enzyme assay}

Enzymatic activities of all the samples were expressed in units of activity per liter ( $\left.\mathrm{U} \mathrm{mL}^{-1}\right)$. Endo-PG activity was measured viscosimetrically by mixing $5.5 \mathrm{~mL}$ of $1 \%$ $(\mathrm{m} / \mathrm{v})$ citric pectin in $0.2 \mathrm{~mol} \mathrm{~L}^{-1}$ acetate buffer at $\mathrm{pH} 5.0$ (supplemented with $1 \mathrm{mmol} \mathrm{L}{ }^{-1}$ EDTA), with $250 \mu \mathrm{L}$ of the crude enzyme. The reaction was incubated for $30 \mathrm{~min}$ at $45{ }^{\circ} \mathrm{C}$ and then cooled in an ice bath. A viscosimetric unit (U) was defined as the enzyme quantity required to decrease the initial viscosity per minute by $50 \%$ under the conditions previously described. ${ }^{12}$ Exo-PG activity was assayed by measuring the release of reducing groups from citric pectin using the 3,5-dinitrosalicylic acid (DNS) assay. ${ }^{13,14}$ The reaction mixture containing $0.5 \mathrm{~mL} 1 \%$ citric pectin in $0.2 \mathrm{~mol} \mathrm{~L}^{-1}$ acetate buffer, $\mathrm{pH} 5.0$ and $0.5 \mathrm{~mL}$ of enzymatic extract was incubated at $45^{\circ} \mathrm{C}$ for $30 \mathrm{~min}$. One unit of enzymatic activity (U) was defined as the amount of enzyme releasing $1 \mu \mathrm{mol}$ of galacturonic acid per minute.

\section{Optimization procedure}

Once the variables having the greatest influence on the responses were identified, a central composite design was used to optimize the levels of these variables. For the three factors, this design was made up of a central composite design with four cube points; that is, a point for one factor having an axial distance from the centre (that is, level 0 ) of $\pm \alpha$, while the other factor is at level 0 (Table 1). The axial distance $\alpha$ was chosen to be 1.682 to make this design orthogonal. So the coded values $-\alpha$ and $\pm \alpha$ are -1.682 and 1.682 , respectively. The computer software DESIGN EXPERT vision 8.05b (Stat-Ease Inc., Minneapolis, USA) was used to estimate the responses of the dependent variables. ${ }^{15}$ This approach has been successfully applied to optimize medium composition, condition of enzyme reaction, and extraction conditions for bioactive compounds. ${ }^{16,17}$ In this study, a central composition design was applied to optimize medium condition of exo-PG by A. niger in flask culture. As seen from Table 2, the experiment was carried out with 3 factors with 5 levels based on preliminary single experimental results. The exo-PG yield was chosen as the response.

Table 1. Experimental range and levels of the independent process variables according to the central composite design

\begin{tabular}{lccccc}
\hline \multirow{2}{*}{ Variable } & \multicolumn{5}{c}{ Level of variable $/\left(\mathrm{g} \mathrm{L}^{-1}\right)$} \\
\cline { 2 - 6 } & -1.682 & -1 & 0 & -1 & 1.682 \\
\hline Fructose & 23.20 & 30.00 & 40.00 & 50.00 & 56.80 \\
Peptone & 2.30 & 3.00 & 4.00 & 5.00 & 5.70 \\
Pectin & 0.60 & 2.00 & 4.00 & 6.00 & 7.40 \\
\hline
\end{tabular}

\section{Enzyme purification procedure}

After 72 hours of fermentation, the culture broth was centrifuged at $9,000 \times \mathrm{g}$ for $15 \mathrm{~min}$, and the resulting supernatant was filtered through a membrane filter ( $0.45 \mu \mathrm{m}$, Millipore). The culture filtrate was precipitated by ammonium sulfate $(20-100 \%)$ and the mixture was stirred for $2 \mathrm{~h}$, and centrifuged at $15,000 \times \mathrm{g}$ for $30 \mathrm{~min}$. The ammonium sulfate fraction was dialyzed against Tris- $\mathrm{HCl}$ buffer (50 mmol L-1, $\mathrm{pH}$ 6.5) and directly loaded on a Sepharose CL-6B gel filtration column $(2.5 \times 60 \mathrm{~cm})$ equilibrated with $13 \mathrm{mmol} \mathrm{L}{ }^{-1} \mathrm{Na}_{2} \mathrm{HPO}_{4^{-}}$ citric acid buffer ( $\mathrm{pH}$ 5.0). Protein fractions collected from the column, corresponding to the protein peak, were pooled, concentrated and further applied to the DEAE-Sepharose FF based anion exchangers column equilibrated with $20 \mathrm{mmol} \mathrm{L}-1 \mathrm{Na}_{2} \mathrm{HPO}_{4}$-citric acid buffer (pH 6.5). ${ }^{18}$ Fractions of $4 \mathrm{~mL}$ were collected and assayed 
Table 2. Central composite design of variables with exo-PG production as the response after 48 hours of incubation in flask culture

\begin{tabular}{|c|c|c|c|c|}
\hline Run & $\begin{array}{l}\text { Fructose A / } \\
\qquad\left(\mathrm{g} \mathrm{L}^{-1}\right)\end{array}$ & $\begin{array}{l}\text { Peptone B / } \\
\qquad\left(\mathrm{g} \mathrm{L}^{-1}\right)\end{array}$ & $\begin{array}{l}\text { Pectin C / } \\
\quad\left(\mathrm{g} \mathrm{L}^{-1}\right)\end{array}$ & $\begin{array}{c}\text { Enzymatic } \\
\text { activity Y / } \\
\left(\mathrm{U} \mathrm{mL}^{-1}\right)\end{array}$ \\
\hline 1 & 40.00 & 4.00 & 4.00 & 18.32 \\
\hline 2 & 30.00 & 5.00 & 2.00 & 9.47 \\
\hline 3 & 40.00 & 4.00 & 4.00 & 19.16 \\
\hline 4 & 30.00 & 3.00 & 2.00 & 21.43 \\
\hline 5 & 30.00 & 3.00 & 6.00 & 18.02 \\
\hline 6 & 40.00 & 4.00 & 4.00 & 18.86 \\
\hline 7 & 40.00 & 5.70 & 4.00 & 15.25 \\
\hline 8 & 56.80 & 4.00 & 4.00 & 11.92 \\
\hline 9 & 40.00 & 2.30 & 4.00 & 19.01 \\
\hline 10 & 23.20 & 4.00 & 4.00 & 14.64 \\
\hline 11 & 40.00 & 4.00 & 7.40 & 18.99 \\
\hline 12 & 50.00 & 5.00 & 6.00 & 21.68 \\
\hline 13 & 40.00 & 4.00 & 4.00 & 15.42 \\
\hline 14 & 40.00 & 4.00 & 4.00 & 19.12 \\
\hline 15 & 50.00 & 3.00 & 6.00 & 13.71 \\
\hline 16 & 30.00 & 5.00 & 6.00 & 15.53 \\
\hline 17 & 50.00 & 5.00 & 2.00 & 10.68 \\
\hline 18 & 40.00 & 4.00 & 4.00 & 18.72 \\
\hline 19 & 40.00 & 4.00 & 0.60 & 12.57 \\
\hline 20 & 50.00 & 3.00 & 2.00 & 11.92 \\
\hline
\end{tabular}

for exo-PG activity. The objective of this procedure was to purify the exo-PG present in the crude enzyme solution. The protein fraction with exo-PG activity was pooled, desalted overnight by dialysis at $4{ }^{\circ} \mathrm{C}$, freeze-dried and kept refrigerated until use.

\section{Analytical electrophoresis}

The relative molecular weight of the purified enzyme was determined by sodium dodecyl sulfate polyacrylamide gel electrophoresis (SDS-PAGE) in a Mini Protean II apparatus $(10 \times 8 \mathrm{~cm})($ Biorad $)$. Electrophoresis was carried out in a vertical slab gel apparatus (Beijing Liuyi Instrument Factory, DYCZ-24DN) with a $5 \%(\mathrm{~m} / \mathrm{v})$ polyacrylamide stacking gel and $12 \%(\mathrm{~m} / \mathrm{v})$ resolving gel in Tris/glycine buffer ( $\mathrm{pH}$ 8.3). Molecular mass of purified exo-PG was estimated using the Sigma molecular weight marker MP102 $(14.4-94.0 \mathrm{kDa})$ in a parallel lane. ${ }^{19}$ The proteins were visualized by silver staining.

\section{Protein estimation}

The protein concentration was determined in the concentration ranges of $1-10$ and $10-100 \mu \mathrm{g} \mathrm{mL} \mathrm{m}^{-1}$ by the
Bradford microassay, using bovine serum albumin (BSA) as standard..$^{20}$

\section{Properties of purified enzyme}

All enzyme catalytic properties were assayed with $1 \%$ citrus pectin [degree of esterification (D.E.) $67-70 \%$ ] as substrate using the procedure for enzyme activity determination described above and carried out with three replicates. Exo-PG activity was assayed as a function of $\mathrm{pH}$ ranging from 3.0 to 8.0 in $\mathrm{Na}_{2} \mathrm{HPO}_{4}$-citric acid buffer at $45^{\circ} \mathrm{C}$, and temperature, in $\mathrm{Na}_{2} \mathrm{HPO}_{4}$-citric acid buffer at the $\mathrm{pH}$ optimum, incubated at different temperatures between 35 and $60{ }^{\circ} \mathrm{C}$.

The thermal stability was investigated by remeasuring the activity of the purified enzyme solution after it had been kept for $2 \mathrm{~h}$, in the absence of substrate, at different temperature in the range $30-60^{\circ} \mathrm{C}$. In these tests, the initial and final exo-PG activities were determined at optimum $\mathrm{pH}$ and temperature. The $\mathrm{pH}$ stability of the purified enzyme was evaluated by dispersing $(1: 1, \mathrm{v} / \mathrm{v})$ enzyme solution in $\mathrm{Na}_{2} \mathrm{HPO}_{4}$-citric acid buffer ( $\mathrm{pH} 3.0-8.0)$ and maintaining these solutions at $45^{\circ} \mathrm{C}$ for 4 hours. An aliquot was taken to determine the remaining activity at the optimum $\mathrm{pH}$ and temperature.

The Michaelis constant $\left(\mathrm{K}_{\mathrm{m}}\right)$ and maximum velocity $\left(\mathrm{V}_{\text {max }}\right)$ values of the enzyme were determined by measuring the reaction velocity measured with $67-70 \%$ D.E. citrus pectin (Sigma) as substrate, at concentrations between 2.0 and $40.0 \mathrm{mg} \mathrm{mL}^{-1}$ at optimum $\mathrm{pH}$ and temperature. According to the Michaelis-Menten enzyme kinetics, the reciprocal of the reaction velocity (1/V) was plotted against the reciprocal of the substrate concentration (1 / [S]) to determine the $\mathrm{K}_{\mathrm{m}}$ and $\mathrm{V}_{\max }$ values by the Lineweaver-Burke plot. The results were plotted with Excel.

\section{Results and Discussion}

\section{Confirmation of enzyme type}

Cell-free supernatant of Aspergillus niger SW06 was found to be predominantly exo-PG activity with fewer amounts of endo-PG (Figure 1).

\section{Production of exo-PG in flask culture}

In general, enzyme production is influenced by the composition of the medium, in particular the carbon and nitrogen sources. ${ }^{21}$ Table 2 summarized the central composite experimental plan along with the experimental responses for each individual experiment. By applying 


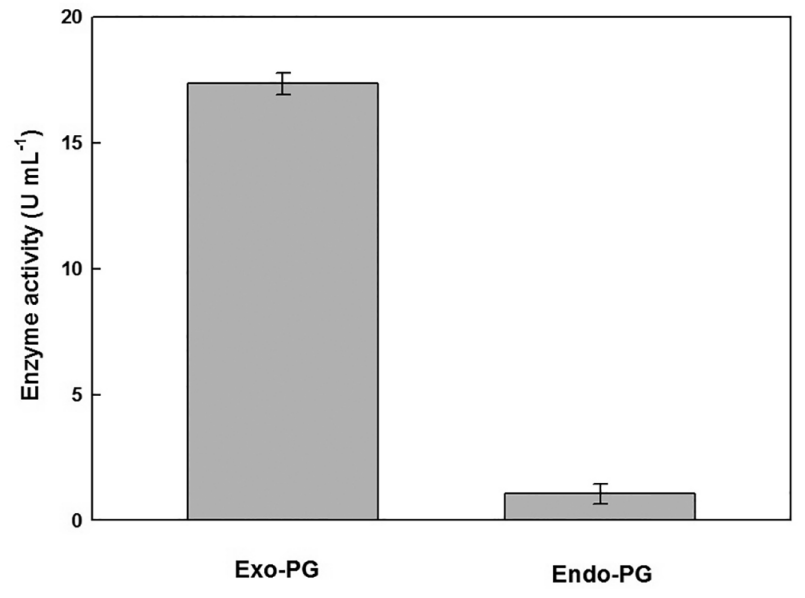

Figure 1. Comparative enzyme activity of exo-PG and endo-PG.

multiple regression analysis on the experimental data, the following second order polynomial equation was found to represent the exo-PG production adequately:

$\mathrm{Y}=18.26-0.81 \mathrm{~A}-1.03 \mathrm{~B}+1.92 \mathrm{C}+2.65 \mathrm{AB}+$ $1.27 \mathrm{AC}+2.34 \mathrm{BC}-1.75 \mathrm{~A}^{2}-0.38 \mathrm{~B}^{2}-0.86 \mathrm{C}^{2}$

where $\mathrm{Y}$ represents the response variable. A, B and C represent the coded values of fructose, peptone and pectin, respectively. The regression equation was optimized by the DESIGN EXPERT to get the optimum values. The optimal values of the test variables, in uncoded levels are as follows: fructose $=48.9$, peptone $=5.0$ and pectin $=6.0$.

For testing the goodness of fit of the model, the multiple coefficient of correlation (R) and the determination coefficient $\left(\mathrm{R}^{2}\right)$ were evaluated. The coefficient of determination, $\mathrm{R}^{2}$, indicates that about $93.3 \%$ of the total variability in the response could be explained by the model. The value of $R$ is 0.9965 , which indicates that the regression model explained the reaction well. The analysis of variance (ANOVA) of the quadratic regression model demonstrated that equation 1 is highly statistically significant model of exo-PG response, as was evident from the Fisher's test with a very low probability value $[(p$ model $>F)=0.0001]$. The model $\mathrm{F}$ value of 25.68 implied that the model was significant. There was only a $0.01 \%$ chance that the "model $F$ value" could occur because of noise.

In order to confirm the optimization results, the suggested medium components were confirmed in triplicate. The $21.63 \mathrm{U} \mathrm{mL}^{-1}$ exo-PG was maximally obtained under the optimum conditions just described, where the corresponding experimental response was $21.51 \pm 0.11$. This implied that the selected conditions were really the most suitable. Gattás et al. ${ }^{22}$ found that the optimal pectin level was $2.0 \%(\mathrm{~m} / \mathrm{v})$ for exo-PG production by Aspergillus sp. $\mathrm{CC} 1$ in submerged culture, which suggests that the level of substance requirement for exoPG production depends on the nature of the specific strain, though they belong to the same species (i.e., Aspergillus).

\section{Purification of exo-PG}

The exo-PG was purified through Sepharose CL-6B column and DEAE-Sepharose FF column. As showed in Table 3, total protein content of the sample decreased from $91.2 \mathrm{mg}$ in the crude sample to $1.96 \mathrm{mg}$ in the final step. The specific activity had a marked increase in every step, i.e., from $140.35 \mathrm{U} \mathrm{mg}^{-1}$ in the crude sample to $382.65 \mathrm{U} \mathrm{mg}^{-1}$ in the final chromatographic step. Total enzyme activity in the crude sample was $12800 \mathrm{U}$. The yield of the enzyme was $5.9 \%$ with respect to the starting material. The enzyme solution separated on a Sepharose CL-6B column, afforded one single peak of exo-PG activity suggesting one fraction (Figure 2a). Exo-PG was collected for further purification to confirm its purity. When the exo-PG solution was concentrated and loaded on a DEAE-Sepharose FF column, still only one PG peak was eluted (Figure 2b). The results were different with the reports of Kant et al., ${ }^{9}$ who observed two subunits of PG separated from A. niger MTCC 3323 by Sephacryl S-200 gel-filtration chromatography.

\section{Characterization of exo-PG}

The homogeneity of the purified exo-PG was demonstrated by the presence of one single protein band on polyacrylamide gel and its molar mass was estimated to be $66.2 \mathrm{kDa}$ as single subunit (Figure 3). This observation was in the range reported for exo-PGs from several fungi, which have molecular weight ranging from 20 to $95 \mathrm{kDa}^{21,23}$ The molecular mass of the PG from A. niger NRRL3 was $32 \mathrm{kDa}$ as estimated by gel filtration and sodium dodecyl

Table 3. Purification of exo-PG produced by A. niger SW06

\begin{tabular}{lccccc}
\hline Purification step & Total activity / & Total protein / mg & $\begin{array}{c}\text { Specific activity / } \\
\left(\mathrm{U} \mathrm{mg}^{-1}\right)\end{array}$ & Purification fold & Yield / \% \\
\hline Crude filtrate & 12800 & 91.20 & 140.35 & 1.00 & 100.0 \\
Sepharose CL-6B & 1820 & 8.34 & 218.23 & 1.56 & 14.2 \\
DEAE-Sepharose FF & 750 & 1.96 & 382.65 & 2.73 & 5.9 \\
\hline
\end{tabular}



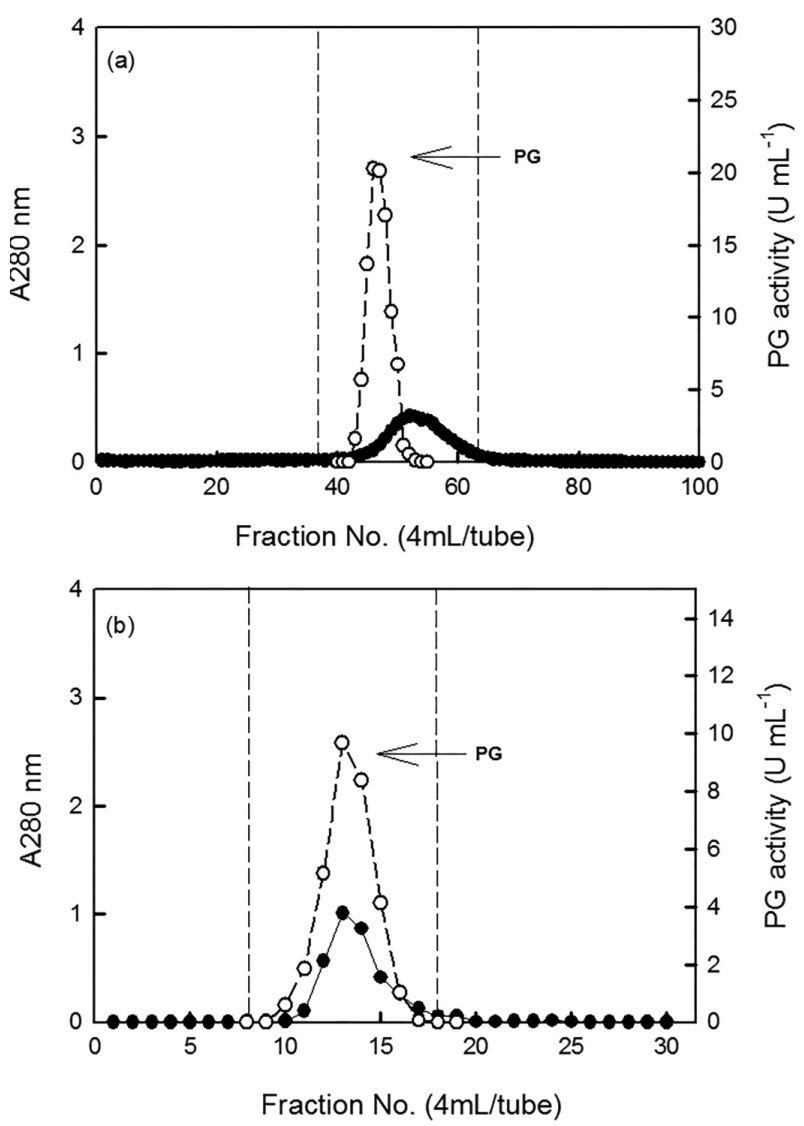

Figure 2. Elution of exo-PG from Sepharose CL-6B gel filtration column previously equilibrated with $13 \mathrm{mmol} \mathrm{L} \mathrm{Na}_{2} \mathrm{HPO}_{4}$-citric acid buffer (pH 5.0) (a) and DEAE-Sepharose FF column based anion exchangers column equilibrated with $20 \mathrm{mmol} \mathrm{L}{ }^{-1} \mathrm{Na}_{2} \mathrm{HPO}_{4}$-citric acid buffer (pH 6.5) (b). Protein (-); exo-PG activity (O).

sulfate-polyacrylamide gel electrophoresis. ${ }^{24}$ In contrast, a heterodimer of 34 and $69 \mathrm{kDa}$ subunit was detected for PG from A. niger MTCC 3323, ${ }^{9}$ and two exo-PGs 1 and 2 from another $A$. niger had the molecular masses of 82 and $56 \mathrm{kDa}$, respectively. ${ }^{25}$

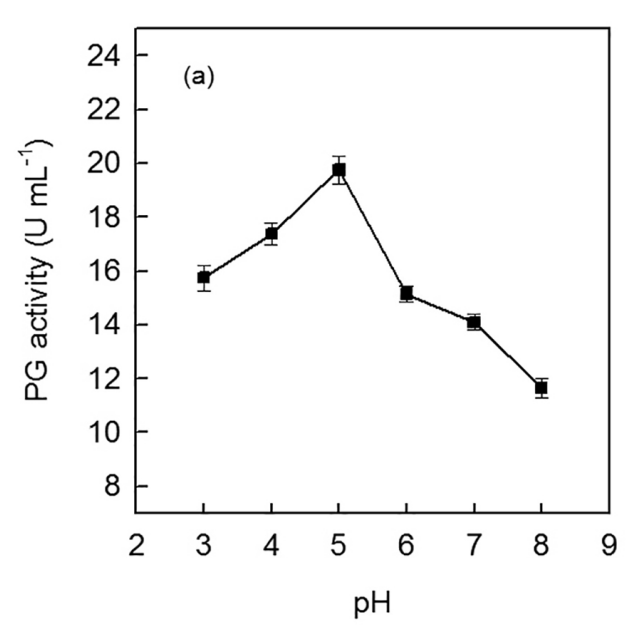

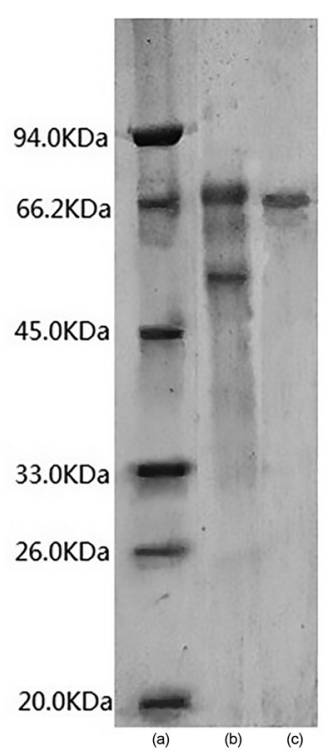

Figure 3. SDS-PAGE of standard proteins (a); crude exo-PG (b) and purified exo-PG (c) from DEAE-Sepharose FF chromatography.

The effect of $\mathrm{pH}$ on the A. niger exo-PG activity toward polygalacturonic acid was examined at $45{ }^{\circ} \mathrm{C}$. As shown in Figure 4a, the enzyme showed hydrolase activity from pH 3.0 to 8.0 , and maximum activity $\left(19.76 \mathrm{U} \mathrm{mL}^{-1}\right)$ at $\mathrm{pH}$ 5.0. The same $\mathrm{pH}$ optimum was reported for PGs from Aspergillus niger ${ }^{26}$ The effect of $\mathrm{pH}$ on the stability of A. niger exo-PG was investigated by incubating the enzyme at $45{ }^{\circ} \mathrm{C}$ at different $\mathrm{pH}$ 's for $4 \mathrm{~h}$. The results showed that the enzyme was the most stable in the $\mathrm{pH}$ of 5.0 , with $90-100 \%$ of the full activity in a broader $\mathrm{pH}$ range of 3.0-5.0 (Figure $4 \mathrm{~b}$ ). The results are very close to the results reported by Mallu et al. ${ }^{27}$ for A. niveus exo-PG. They reported that exo-PG showed $\mathrm{pH}$ stability between 3.0 and 5.0. Sakamoto et al..$^{25}$ reported that the optimum activities occurred at $\mathrm{pH}$ 3.4-3.8 for exo-PG1 and 3.4-4.2 for exo-PG2 from another A. niger, respectively. In contrast,

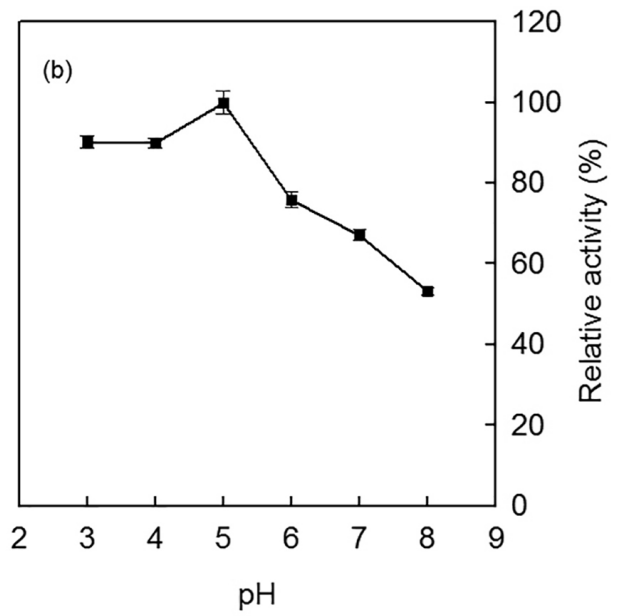

Figure 4. Effect of pH on exo-PG activity (a) and exo-PG stability (b). 

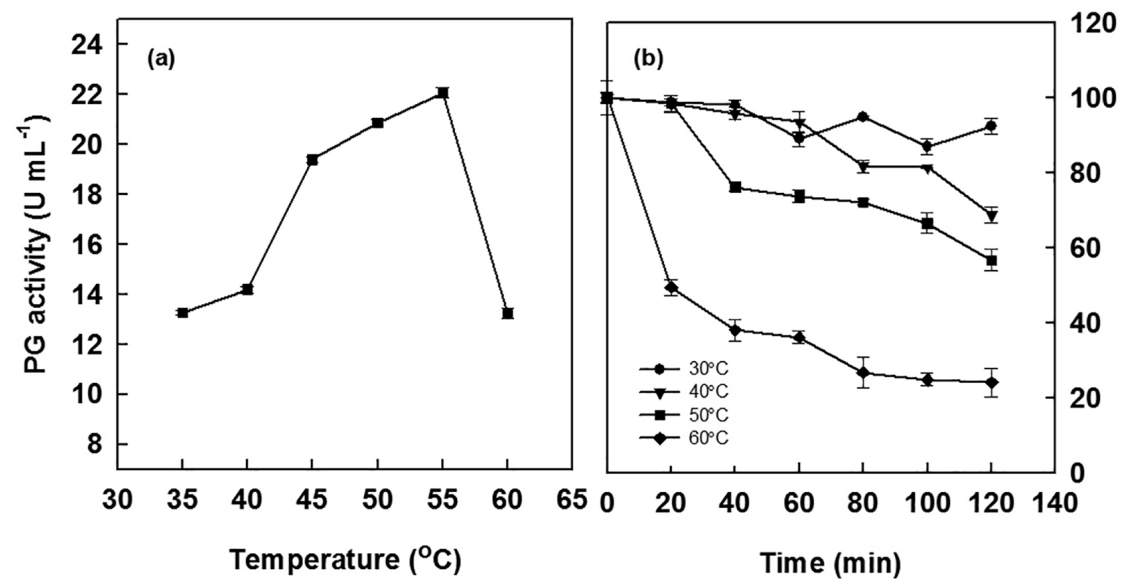

120

100

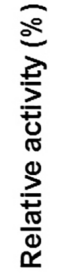

Figure 5. Effect of temperature on exo-PG activity (a) and exo-PG stability (b).

the PG from A. kawachii had an optimum activity at low $\mathrm{pH}(2.0-3.0){ }^{28}$ The highest $\mathrm{pH}$ optimum value of $\mathrm{pH} 10.0$ was observed for PG from Bacillus sp. MG-cp-2. ${ }^{29}$

With respect to temperature, the purified exo-PG exhibited optimum activity of $55^{\circ} \mathrm{C}$ as depicted in Figure $5 \mathrm{a}$. Earlier similar results were obtained that the temperature optima for PGs from other A. niger PGs were around 37 and $45^{\circ} \mathrm{C} .{ }^{9,24,30}$ The effect of temperature on thermal stability of A. niger exo-PG was investigated by incubation the enzyme for $2 \mathrm{~h}$ in $13 \mathrm{mmol} \mathrm{L}^{-1} \mathrm{Na}_{2} \mathrm{HPO}_{4}$-citric acid buffer, $\mathrm{pH} 5.0$ at different temperatures ranging from 30 to $60^{\circ} \mathrm{C}$ prior to substrate addition (Figure $5 \mathrm{~b}$ ). In the absence of substrate for $1 \mathrm{~h}$, exo-PG showed $36-89 \%$ of the original activity at $30-60{ }^{\circ} \mathrm{C}$. After $2 \mathrm{~h}$, exo-PG showed $57-88 \%$ of the original activity at $30-50{ }^{\circ} \mathrm{C}$, while at $60{ }^{\circ} \mathrm{C}$, the enzyme lost $76 \%$ of its initial activity. Kant et al..$^{9}$ observed that at $45^{\circ} \mathrm{C}$ the relative activity of A. niger PG after 30 min of incubation was to be $45.23 \%$, i.e., it lost more than half of its activity.

The kinetic parameters of $A$. niger exo-PG affinity for citrus pectin in a range of 2.0 and $40.0 \mathrm{mg} \mathrm{mL}^{-1}$ at $\mathrm{pH} 5.0$ and $45^{\circ} \mathrm{C}$ were determined by a typical double reciprocal Lineweaver-Burk plot (Figure 6). According to the Figure 5, the $\mathrm{K}_{\mathrm{m}}$ and $\mathrm{V}_{\max }$ for the enzyme were calculated as $0.58 \mathrm{mg} \mathrm{mL}^{-1}$ and $20.66 \mu \mathrm{mol}(\mathrm{mL} \mathrm{min})^{-1}$, respectively. The $\mathrm{K}_{\mathrm{m}}$ values of A. niger exo-PG in this study were lower than $\mathrm{K}_{\mathrm{m}}\left(2.5 \mathrm{mg} \mathrm{mL}^{-1}\right)$ of $\mathrm{PG}$ from another A. niger. ${ }^{31}$ The reason for low $\mathrm{K}_{\mathrm{m}}$ may be due to the high affinity of A. niger exo-PG using citrus pectin as substance. ${ }^{24} \mathrm{The} \mathrm{V}_{\max }$ of $A$. niger exo-PG was in the range of $\mathrm{V}_{\max }$, i.e., 13.0 to $2600 \mu \mathrm{mol}(\mathrm{mL} \mathrm{min})^{-1}$ from above three organisms.

\section{Conclusion}

In the present study, a statistical method, central composition design was applied to the optimization of medium composition for maximum exo-PG production

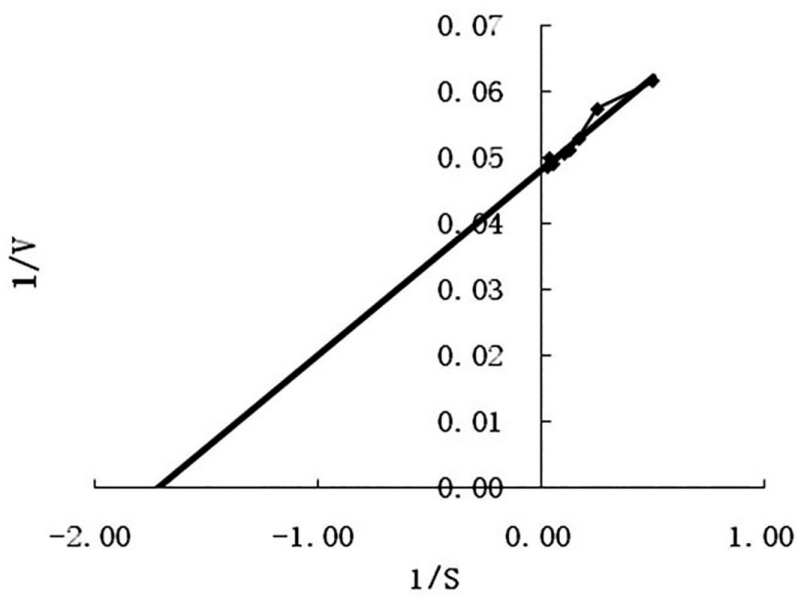

Figure 6. Lineweaver-Burke plot for purified exo-PG (the units of $\mathrm{S}$ and $\mathrm{V}$ are $\mathrm{mg} \mathrm{mL}^{-1}$ and $\mu \mathrm{mol}(\mathrm{mL} \mathrm{min})^{-1}$, respectively).

from A. niger SW06. This enzyme kept the stability in a $\mathrm{pH}$ range of 3.0-5.0 and at a temperature range of $30-60{ }^{\circ} \mathrm{C}$. To our knowledge, this exo-PG from A. niger SW06 is more thermostable and acid-resisting, comparing the PGs from other several fungi. The thermostable and acidic nature for activity makes it possible to have wide range of industrial applications. Further works on scale-up fermentation optimization in bioreactor and industrial application are in progress in our laboratory.

\section{Acknowledgments}

This work was supported by the National Science Foundation of China (Grant No. B060806).

\section{References}

1. Ward, O. P.; Moo-Young, M.; Crit. Rev. Biotechnol. 1989, 8, 237.

2. Niture, S. K.; Biologia 2008, 63, 1. 
3. Joslyn, N. A.; Mist, S.; Lambart, E.; Food Technol. 1952, 6, 133.

4. Sakai, T.; Sakamoto, T.; Hallaert, J.; Vandamme, E. J.; $A d v$. Appl. Microbiol. 1993, 39, 213.

5. Dey, T. B.; Adak, S.; Bhattacharya, P.; Banerjee, R.; LWT -- Food Sci. Technol. 2014, 59, 591.

6. Mathew, A.; Eldo, A. N.; Molly, A. G.; J. Ind. Microbiol. Biotechnol. 2008, 35, 1001.

7. Murad, H. A.; Azzaz, H. H.; Res. Microbiol. 2011, 6, 246.

8. Hoondal, G. S.; Tiwari, R. P.; Tewari, R.; Dahiya, N.; Beg, Q. K.; Appl. Microbiol. Biotechnol. 2002, 59, 409.

9. Kant, S.; Vohra, A.; Gupta, R.; Protein Expression Purif. 2013, 87, 11.

10. Borin, M. D. F.; Said, S.; Fonseca, M. J. V.; J. Agric. Food Chem. 1996, 44, 1616.

11. Niture, S. K.; Pant, A.; Microbiol. Res. 2004, 159, 305.

12. Tuttobello, B. R.; Mill, P. J.; Biochem. J. 1961, 79, 51.

13. Miller, G. L.; Anal. Bioanal. Chem. 1959, 31, 426.

14. Martins, E. S.; Silva, D.; Da Silva, R.; Gomes, E.; Process Biochem. 2002, 37, 949.

15. Wang, H.; Zhang, X.; Dong, P.; Luo, Y.; Cheng, F.; Int. J. Pharmacol. 2013, 9, 288.

16. Hong, Z.; Lin, Z.; Liu, Y.; Tan, G.; Lou, Z.; Zhu, Z.; Chai, Y.; Fan, G.; Zhang, J.; Zhang, L.; J. Chromatogr. A 2012, 1254, 14.

17. Zhao, Q.; Kennedy, J. F.; Wang, X.; Yuan, X.; Zhao, B.; Peng, Y.; Huang, Y.; Int. J. Biol. Macromol. 2011, 49, 181.

18. Mohamed, S. A.; Farid, N. M.; Hossiny, E. N.; Bassuiny, R. I.; J. Biotechnol. 2006, 127, 54.
19. Laemmli, U.; Nature 1970, 227, 680.

20. Bradford, M. M.; Anal. Biochem. 1976, 72, 248.

21. Gomes, E.; Leite, S. R. R.; Da Silva, R.; Silva, D.; Int. J. Food Microbiol. 2009, 10, 1155.

22. Gattás, E. A. L.; Bueno, M. R.; Ribeiro, M. H. L.; Eur. Food Res. Technol. 2009, 229, 923.

23. Silva, D.; Martins, E. S.; Leite, R. S. R.; Da Silva, R.; Ferreira, V.; Gomes, E.; Process Biochem. 2007, 42, 1237.

24. Fahmy, A. S.; El-beih, F. M.; Mohamed, S. A.; Abdel-Gany, S. S.; Abd-Elbaky, E. A.; Appl. Biochem. Biotechnol. 2008, 149, 205.

25. Sakamoto, T.; Bonnin, E.; Quemener, B.; Thibault, J. F.; Biochim. Biophys. Acta, Gen. Subj. 2002, 1572, 10.

26. Behere, A.; Satyanarayan, V.; Padwal-Desai, S. R.; Enzyme Microb. Technol. 1993, 15, 158.

27. Mallu, A.; Damasio, A. R.; Da Silva, T. M.; Jorge, J. A.; Terenzi, H. F.; Mde, L.; Enzyme Res. 2011, 10, 4061.

28. Contreas-Esquivel, J. C.; Voget, C. E.; J. Biotechnol, 2004, 110, 21.

29. Kapoor, M.; Beg, Q. K.; Bhushan, B.; Dadhich, K. S.; Hoondal, G. S.; Process Biochem. 2000, 36, 467.

30. Gomes, J.; Zeni, J.; Cence, K.; Toniazzo, G.; Treichel, H.; Food Bioprod. Process. 2011, 89, 281.

31. Parenicova, L.; Benen, J. A. E.; Kester, H. C. M.; Visser, J.; Eur. J. Biochem. 1998, 251, 72.

Submitted: April 14, 2016 Published online: July 14, 2016 